\title{
Evaluation of Sustainability of Current Account Deficits in Turkey
}

\author{
Aysu Insel $^{1}$, Fazil Kayikci ${ }^{2}$ \\ ${ }^{1}$ Department of Economics, Marmara University, Istanbul, Turkey \\ ${ }^{2}$ Department of Economics, Yildiz Technical University, Istanbul, Turkey \\ Email: ainsel@marmara.ed.tr, fkayikci@yildiz.edu.tr
}

Received September 30, 2011; revised November 5, 2011; accepted December 10, 2011

\begin{abstract}
Sustainability of the current account deficits in Turkey was evaluated according to the macroeconomic fundamentals together with discussing the composition of current account deficit and the way of financing to have insights about the future path of current account balance. Problem about current account deficits were considered as structural since they were caused by foreign trade deficits largely as an outcome of dependence of production and exports on imported intermediate goods. Furthermore, there were negative developments about the way of financing in last years that share of debt instruments in financing has increased against Foreign Direct Investment. As a result, it has seen that Turkey would continue to have current account deficits in the next years and sustainability of these deficits has become increasingly difficult.
\end{abstract}

Keywords: Current Account; Balance of Payments; Sustainability

\section{Introduction}

The pattern of current account imbalances has received considerable attention in the economics literature for many years. However, in the 1990 s, it became a very popular subject for investigation for economists due to the frequent balance of payments crises that broke in various parts of the world. These took the form of currency crises accompanied by substantial capital outflows. In the late 1970 s and early 1980s, there were few cases of currency crises especially in Latin America. Later in 1992, the European exchange rate mechanism (ERM) collapsed. In 1994, Mexican peso crisis and subsequent currency crises in the Latin America arouse, followed by a wave of currency crises of Asia in 1997 and 1998. Finally it was in Turkey at the beginning and in Argentina at the end of 2001 that we witnessed the collapse of local currencies followed by free floating of the currencies. These series of crises in the last decade were so frequent that the existing models were inadequate in explaining them; hence, a significant collection of studies accumulated, giving way to different interpretations of the currency and balance of payments crises. Also, policymakers and economists have paid more attention and to work more frequently on the issue. This has increased the volume of studies about the measures of sustainable current account deficits in the economic literature. Researches are especially concentrated on the issue that whether the deficits result with a balance of payments crisis or not. In this respect, some sustainability criteria were developed and these were used as indicators for the crises.

Current account deficit as a ratio to Gross Domestic Product (GDP) is a simple and commonly used method, which provides an opinion on the sustainability of the current account deficits. However, an evaluation based on this ratio may not always provide sufficient information on the sustainability of the current account deficits of a country since it ignores the specific characteristics of different economies. Different current account deficit to GDP ratios can be accepted as sustainable for different countries according to the financial and macroeconomic fundamentals of those countries. Thus, more comprehensive concepts have been proposed in the recent economics literature to evaluate whether the persistent current account deficits impose serious problems. These concepts are; solvency of foreign debt, excessiveness of the current account deficit and sustainability of the current account deficit.

Solvency is theoretically defined in relation to a country's present value budget constraint. "A country is solvent if its discounted value of the expected stock of foreign debt in the infinitely distant future is non-positive." (Corsetti, Presenti and Roubini, 1998, p.8) [1]. If a country has a current account deficit today, which has to be repaid in the future with an interest payment, it must have trade surpluses at some date in the future. A country is considered to be solvent if its economy has a capacity to 
generate enough trade surpluses to pay the current debt in the future.

Sustainability is defined as a case where current economic policies can be maintained at the same time fulfilling the solvency condition (Milesi-Ferretti and Razin) [2]. In other words, the current account deficit of a country is sustainable if the continuation of the current macroeconomic policy in the future does not violate the solvency constraint; or the ratio of external debt to GDP can be maintained at stable levels. Hence, sustainability should not require any drastic shift in the economic policies or lead to crisis in order to ensure solvency. On the contrary, if the solvency criterion is obtained by a shift in the economic policies, then the current account deficit will be regarded as unsustainable.

Excessiveness can only be measured by relying on a model that specifies the behavior of consumption, investment, output and yields predictions about the equilibrium external imbalances. Actual imbalances can then be compared to the theoretically predicted ones in order to judge whether the imbalances have been excessive or not. (Milesi-Ferretti and Razin) [2]. Different empirical approaches have emerged to measure the excessiveness of the current account deficits in the literature; Glick and Rogoff [3] rely on structural estimation of the model and focus on estimated responses to various types of shocks whereas Ghosh and Ostry [4] use vector auto regression analysis to estimate the consumption-smoothing current account.

Most studies have used the econometric techniques such as unit roots and cointegration analyses in order to evaluate the notion of sustainability. A common feature in existing literature is the finding of nonstationary current accounts using unit root tests such as $\mathrm{Wu}$ [5] for Organization of Economic Cooperation Countries (OECD). Another approach is to examine the cointegration between exports and imports such as Husted [6], Leachman and Francis [7] and $\mathrm{Wu}$, Chenn and Lee [8] for Group of Seven Countries, (G7). There are also some studies that apply both methodology such as Baharumshah, Lau and Fountas [9] and Ongan [10]. Furthermore, some researchers apply these methodologies by using intertemporal solvency approach such as Kalyoncu [11], Matsubayashi [12], Campa and Gavilan [13], or by using Markov switching process such as Raybaudi, Sola and Spagnolo [14].

However, if we interpret the current account as a dynamic process in which it is determined by the outcome of the actions and expectations of forward looking private agents, these empirical researches will not be sufficient for understanding the sustainability of the current account deficits. The issue should be analyzed both from empirical and theoretical perspectives. For example, the current account deficit may seem to be sustainable with the unit root tests but this can only be true for considering the ability to pay concept; it does not take into account the willingness of foreigners to continue to provide funds for the domestic country to sustain its deficits, furthermore, it does not make judgments about whether the continuing deficits would be desirable or which policies should be implemented to reduce the deficits without deteriorating the other macroeconomic conditions. Thus, the main objective of this paper is to provide theoretical approach to sustain the current account deficit and policy implications by considering the interrelationship of the current account deficit with other economic variables such as the level of international competitiveness, the composition of external liabilities, the strength of the financial system, the degree of political stability, etc.

In the next sections, all of the available knowledge is going to be used and evaluated objectively in order to conclude about the causes and the consequences of the current account deficits in Turkey for recent years. First, composition and evolution of the current account deficit will be undertaken analytically and discussed in terms of some macroeconomic indicators from the points of views of both Turkey and international investors. Second, some manufacturing sectors will be analyzed in terms of forward and backward linkages in terms of import-production dependence. Third, debt structure and financing configurations of current account deficits in Turkey will be provided to reach a conviction about the sustainability position of the deficits. Finally, some conclusions will be presented according to the discussions about the sources of deficits and the way of financing of those deficits.

\section{Evaluation of Composition and Financing of Current Account Deficits}

\subsection{Composition of the Deficits}

When we look at the current account balance of Turkey between 1987 and 2010 Table 1, foreign trade deficit emerges as a leading factor for the deficit in the current account. Without any exception, Turkey had trade deficits in all of the years since 1987 and these deficits were always greater than the deficits in the current account balance. Current account balance had surpluses only in crises years of 1994, 1998 and 2001 where the lessening in the GDP decreases the imports for considerable amounts and narrows the trade deficit. Excessive increases in the trade deficits in 1993 and 2000 (74\% and $125 \%$ respectively) have been perceived as dangerous from the foreign investor's perspective and provided base for the crises through increasing the risk premium and adversely effecting foreigner's willingness to pay. Net income component is another factor for affecting current account balance negatively. Although it has been always in deficit as that was the case for foreign trade, it has not had volatile structure when compared to trade deficits. 
Uygur [15] explains this situation by Net Foreign Asset (NFA) position; since Turkey is a debtor country in international markets; its net interest income is negative which constitutes the high amount of net income component of current account balance. It follows smooth pattern because capital inflows are not realized as high amounts and they react immediately to the interest rate movements by countercyclical which stabilizes the interest payments. Net service income has been effective together with current transfers for decreasing the current account deficits especially for the last years. Net service income is mostly made up from tourism revenues but it does not seem to have an increasing trend. It can be argued that Turkey has not obtained the expected success in the tourism sector even though it had a great potential with its geographical advantages and natural beauties. Besides, in the next years net tourism revenues may not be high enough as it was in the past since the abolishment of visas are expected to effect net tourism revenues negatively (Turkish citizens were facing with more difficulties about visas when they go abroad rather than foreigners who come to Turkey). Current transfers look like as if it decreases after 2002 but this is mainly due to the change in its definition; worker's remittances has been started to be counted in tourism revenues since
2003

To sum up, it can be argued that the current account deficits of Turkey are mainly the result of foreign trade deficits rather than anything else. These kinds of deficits are more dangerous in terms of sustainability and more open to debate about balance of payment crises since they indicate structural weaknesses in international trade and competitiveness. These are permanent problems and cannot be solved easily since changing the production process and technological level of firms require long term planning and investments in education, infrastructure, research and development. For these reasons, analyzing the composition of foreign trade and evolution of trade deficits will be beneficial in order to understand the causes of deficits and structural problems before suggesting policy choices.

Turkey imports particularly investment and intermediate goods while exporting final consumption goods. For the last two decades; 7 percent of Exports of Turkey was made up by investment goods, 44 percent was made up by intermediate goods and 48 percent was made up by consumption goods whereas 19 percent of Imports of Turkey was made up by investment goods, 70 percent was made up by intermediate goods and 10 percent was made up by consumption goods. Hence, current account deficit

Table 1. Current account balance of Turkey.

\begin{tabular}{lccccc}
\hline & Current Account & Trade Balance & Net Service & Net Income & Transfers \\
\hline 1987 & -806 & -3206 & 2162 & -2085 & 2323 \\
1988 & 1596 & -1813 & 3833 & -2513 & 2089 \\
1989 & 938 & -4190 & 4028 & -2327 & 3427 \\
1990 & -2625 & -9448 & 4966 & -2508 & 4365 \\
1991 & 250 & -7290 & 5164 & -2663 & 5039 \\
1992 & -974 & -8076 & 5807 & -2625 & 3920 \\
1993 & -6433 & -14081 & 6740 & -2744 & 3652 \\
1994 & 2631 & -4167 & 7052 & -3264 & 3010 \\
1995 & -2339 & -13152 & 9620 & -3205 & 4398 \\
1996 & -2437 & -10264 & 6657 & -2927 & 4097 \\
1997 & -2638 & -15048 & 10912 & -3013 & 4511 \\
1998 & 2000 & -14038 & 13518 & -2985 & 5505 \\
1999 & -925 & -9771 & 7502 & -3537 & 4881 \\
2000 & -9920 & -22057 & 11375 & -4002 & 4764 \\
2001 & 3760 & -3363 & 9136 & -5000 & 2987 \\
2002 & -626 & -6390 & 7885 & -4554 & 2433 \\
2003 & -7515 & -13489 & 10511 & -5557 & 1020 \\
2004 & -14431 & -22736 & 12797 & -5609 & 1117 \\
2005 & -22198 & -33080 & 15267 & -5839 & 1454 \\
2006 & -32249 & -41056 & 13555 & -6656 & 1908 \\
2007 & -38434 & -46852 & 13283 & -7108 & 2243 \\
2008 & -41959 & -53021 & 17311 & -8362 & 2113 \\
2009 & -13991 & -24850 & 16749 & -8189 & 2299 \\
2010 & -48528 & -56316 & 14270 & -7819 & 1337 \\
\hline
\end{tabular}

Source: CBRT, Balance of Payments Analytical Presentation [16]. 
can be considered as a structural problem; exports largely depend on imported goods. There are some recoveries in these rates in terms of improvements in the structural base; weights of categories have been changing against the consumption goods for the intermediate goods in exports whereas the situation is vice versa in imports. However, those can be considered as negligible. As it is expected from the above rates that foreign trade has been always in deficit for intermediate and investment goods while it had surpluses for consumption goods. Deficits in the intermediate goods were evolved from the 14 billion dollars average in 1990s to 48.5 billion dollars average in 2000 s through reaching its top level to 75 billion dollars in 2010. Deficits in the investment goods were evolved from the 6 billion dollars average in 1990s to 10.5 billion dollars average in 2000s through reaching its top level to 17 billion dollars in 2010. Surpluses in the consumption goods were evolved from the 7 billion dollars average in 1990 s to 18 billion dollars average in 2000s through reaching its top level to 25 billion dollars in 2007.

\subsection{Analyzing the Production Structure}

From the above mentioned realizations about the foreign trade of the Turkish Economy, it can be argued confidently that there is interdependence between exports and imports since Turkey mostly exports final consumption goods whereas it imports intermediate goods. When the industries are ordered according to their volume of exports, it can be seen that top exporters are generally the top importers at the same time. This dependence can also be clarified by the input-output tables. Effect of the unit in- crease in final demand on the imported input requirement of the industries is calculated as the sum of the columns of inverted import matrix. Until now, TURKSTAT has published input-output tables for Turkish economy in 1973, 1979, 1985, 1990, 1996, 1998 and 2002. In Table 2, some of the researches about the imported input requirements of industries, which have used the last published input-output tables 1998, 1998 and 2002 respectively, were presented to understand the import dependence of the production in Turkish economy. If TURKSTAT had published up-to-date input-output tables, it would be more beneficial to understand the current position of the industries in terms of the dependence on imports. However, the last published one is belonged to 2002. The differences in the coefficients for the first two researches have emerged from the different definition and coverage of the industries. In the last research presented in the table, coefficients seem to be significantly higher than the previous works which indicates that the dependence of the production on the import is accelerating. This picture supports the view that current account deficit is mainly the result of growth rather than other determinants. For example, Turkey has to import the 25$27 \%$ (in 1998) or $37 \%$ (in 2002) of the final value of the shoe in order to be able to produce it. After stating the dependence of production to the import sector, Eşiyok [17] also calculated two other indexes to show the dependence of exports to the imports. First one is the ratio of the imported inputs to the total inputs used in the production for some industries. According to his calculations, the ratio of the imported inputs to the total input

Table 2. Coefficients of imported input use in some selected industries.

\begin{tabular}{lccc}
\hline & Yükseler and Türkan [18] & Eşiyok [17] & Ersungur, Ekinci and Takım [19] \\
\hline Food and beverages & 0.11 & - & 0.29 \\
Tobacco and its substitutes & 0.15 & 0.16 & 0.35 \\
Textile & 0.20 & - & 0.34 \\
Clothing & 0.22 & 0.23 & 0.30 \\
Leather and shoes & 0.25 & 0.27 & 0.37 \\
Furniture & 0.30 & - & 0.37 \\
Wood and articles of wood & 0.14 & 0.16 & 0.32 \\
Cork and articles of cork & 0.20 & 0.21 & 0.44 \\
Printed books and newspapers & 0.19 & 0.16 & 0.43 \\
Plastics and articles & 0.30 & 0.37 & 0.39 \\
Rubber and articles & 0.30 & 0.21 & 0.22 \\
Chemicals & 0.30 & 0.35 & 0.61 \\
Fuels and oils & 0.24 & 0.24 & 0.43 \\
Metals & 0.35 & 0.39 & 0.53 \\
Machinery and equipments & 0.30 & 0.26 & 0.44 \\
Railways or tramway locomotives & 0.18 & 0.19 & - \\
Vehicles other than railways & 0.24 & 0.24 & 0.48 \\
Ships, oats and floating structures & 0.18 & 0.21 & 0.70 \\
Pharmaceutical products & - & 0.20 & - \\
Iron and steel & - & 0.36 & - \\
Radio, Television and Telecommunications & 0.29 & - & 0.57 \\
\hline
\end{tabular}


requirements has been steadily increasing; average values for all industries were $7.4 \%$ in $1979,13.6 \%$ in 1985 , $16.7 \%$ in $1990,22 \%$ in 1996 and $23.1 \%$ in 1998 input output tables. Second one is the effect of the unit increase in final demand of exports on the imported input requirement of the industries. According to his calculations, the ratio of the imported inputs to the exports has been modestly increasing; average values for all industries were $5.3 \%$ in $1979,14.8 \%$ in $1985,12.3 \%$ in $1990,11.4 \%$ in 1996 and $15 \%$ in 1998 input-output tables.

\subsection{The Way and the Quality of Financing the Deficits}

Although sustaining current account deficits for countries can be feasible in the short run as long as finding external borrowing, the ability of the country to service its debt by referring to further borrowing is likely to be questioned once the deficit become persistent. As Hakkio [20] states, temporary current account deficits present fewer problems as the imbalances represent the natural outcome of reallocating capital to the country that the factor of production tends to receive the highest possible returns. However, large and persistent current account deficits tend to cause more serious problems for a country and may require a policy response. "They are causes for both domestic and international concern because of undesirable consequences of a forced adjustment in the economic policies if such deficits are expected to continue." (Baharumshah et al., 2003, p. 466) [9]. As Wu (2000) claims, sustaining an increasing current account deficit implies measures such as increasing domestic interest rates relative to foreign to attract more foreign capital for financeing the deficit. This imposes an excessive burden on future generations as the accumulation of larger debt will imply increasing interest payments and thus a lower standard of living. Hence, instead of emphasizing the current account deficits of a country at any particular point in time, economists are more concerned with its sustainability and way of financing. "It is widely argued that current account deficit does not present a problem as long as it is financed. However, how and what conditions this deficit is financed is an important issue because a fast growing current account deficit, even if financed can cause fragility" (Ok, 2008, p. 9) [21]. Composition of international financial obligations has strong influence on the ability of an economy to sustain its deficits. Equity financing such as Foreign Direct Investment (FDI) and portfolio investments do not require payments to investors and share the burden of negative shocks between the home country and international investors. However, debt financing such as bonds and other loans require payments at specific dates and home country bears the whole burden of negative shocks (Milesi-Ferretti and Razin, [2]. Thus, the lower the stream of payments that is required to international investors, the longer the country can run current account deficits.

The structure and composition of these financing alternatives are also important. In case of equity financing; FDI are more stable and have long term structure than portfolio investment and higher FDI can have positive impact on sustainability whereas excessive dependence on portfolio investment increases the potential of a crisis even though both FDI and portfolio investment increase current account deficits through transferring profits. Also, Shelburne [22] argues that portfolio inflows tend to crowd out domestic investment while FDI tends to increase it. In case of debt financing; currency composition, interest rates and maturities determine the vulnerability of country. The higher the share of obligations in the country's own currency, the less vulnerable the country is to negative shocks such as exchange rate adjustments. Hence, a country that issues assets mostly in its own currency, at low interest rates and with a high share of equity can continue along its path of consumption and saving for longer than could a country that borrows in currencies other than its own, at high interest rates with a high share of debt. However, Suarez and Ghezzi [23] argue that FDI can be an indicator of healthier current account deficit only if it is directed to the tradable sectors. "Both the debt and FDI exert similar pressures on the current account. Debt deteriorates future current accounts through interest payments, while FDI does it through profit remittances abroad." ([23], p. 5).

Financing the current account deficit of Turkey for the last two decades is presented in Table 3. First striking fact in the table is the over-financing of the current account deficits. Except for the deficits in the crises years of 1994, 1998 and 2001, surpluses in the financial account have been higher than the deficits in the current account. From the data in this table and detailed representations of current account balance by Central Bank Republic of Turkey (CBRT), it can be claimed that current account deficits of Turkey have been financed increasingly by FDI and long term credits (especially given to the private sector). The share of short term capital flows in total financing has been decreasing. Likewise, foreign exchange reserves of the Central Bank have come to a substantial amount, which can be stand for a safeguard against the sudden outflows. It was above 80 billion dollars at the end of the 2010 when compared to 6.9 billion dollars in 1994 and 18.9 billion dollars levels in 2001. However, financing the current account with FDI and long term credits does not warrant that the deficit will be infinitely sustainable. Furthermore, although Turkey had sound macroeconomic fundamentals and fiscal discipline in the last decade, capital inflows were mostly the result of ample global liquidity. These types of capital inflows, which Yan and Yang [24] defines as 
Table 3. Financing of current account deficits (billion dollars).

\begin{tabular}{|c|c|c|c|c|c|}
\hline & Current Account & Financial Account & Net FDI & Net Portfolio & Net Other Components \\
\hline 1987 & -806 & 1891 & 106 & 282 & 1503 \\
\hline 1988 & 1596 & -958 & 354 & 1178 & -2490 \\
\hline 1989 & 938 & 780 & 663 & 1386 & -1269 \\
\hline 1990 & -2625 & 4037 & 700 & 547 & 2790 \\
\hline 1991 & 250 & -2397 & 783 & 623 & -3803 \\
\hline 1992 & -974 & 3648 & 779 & 2411 & 458 \\
\hline 1993 & -6433 & 8903 & 622 & 3917 & 4364 \\
\hline 1994 & 2631 & -4257 & 559 & 1158 & -5974 \\
\hline 1995 & -2339 & 4565 & 772 & 237 & 3556 \\
\hline 1996 & -2437 & 5483 & 612 & 570 & 4301 \\
\hline 1997 & -2638 & 6969 & 554 & 1634 & 4781 \\
\hline 1998 & 2000 & -840 & 573 & -6711 & 5298 \\
\hline 1999 & -925 & 4829 & 138 & 3429 & 1262 \\
\hline 2000 & -9920 & 9584 & 112 & 1022 & 8450 \\
\hline 2001 & 3760 & $-14,557$ & 2855 & -4515 & $-12,897$ \\
\hline 2002 & -626 & 1172 & 939 & -593 & 826 \\
\hline 2003 & -7515 & 7192 & 1252 & 2465 & 3475 \\
\hline 2004 & $-14,431$ & 17702 & 2005 & 8023 & 7674 \\
\hline 2005 & $-22,198$ & 42,660 & 8967 & 13,437 & 20,256 \\
\hline 2006 & $-32,249$ & 42,689 & 19,261 & 7415 & 16,013 \\
\hline 2007 & $-38,434$ & 48,700 & 19,941 & 833 & 27,926 \\
\hline 2008 & $-41,959$ & 34,558 & 16,955 & -5014 & 22,617 \\
\hline 2009 & $-13,991$ & 9758 & 6858 & 227 & 2673 \\
\hline 2010 & $-48,528$ & 58,957 & 7294 & 16,126 & 35,537 \\
\hline
\end{tabular}

Source: CBRT, Balance of Payments Analytical Presentation [16].

push factors, is more likely to cause current account imbalances in the future. Also, after the huge public enterprises' privatization come to an end and together with 2008 world economic crisis, share of FDI in financing account was much lower than the previous couple of years while the share of portfolio investments sharply increased in 2010. This development has raised the concerns about the sustainability of the current account deficit in Turkey.

\subsection{Foreign Debt Position of the Economy}

"Countries that rely heavily on foreign financing are more prone to quick reversals in foreign investment and that these quick reversals can induce considerable pain like decreasing equity prices, low growth and a sharp depreciation" (Freund and Warnock, 2005, p. 13 [25]). Vulnerability of the countries to the external shocks is generally measured by the ratios of the short term external debt to the total debt, to the reserves of the central bank or to the GDP. If the foreign debt stock (especially the short term debt) of a country increase, the rate of interest it has to pay is going to increase since its risk premium are considered to be high by the international investors. In Table 4, it can be seen that the total foreign debt stock of Turkey has been continuously increasing with exceptions in the crises. However, the ratio of this debt to the GDP has become stable as a result of high growth rates obtained in the last decade. Also, it can be thought as more confident when compared to most of the developing countries in terms of the ratio of short term debt to the total and the ratio of public debt to the private debt. Again, as in the case of portfolio investment, rate of the short term debt of the private sector has sharply increased from 0.16 to 0.25 in 2010 . This situation reminds the South Korea case in the Asian crisis in which local firms have borrowed from their own entities established in abroad. These have raised the concerns about the sustainability of the current account deficit in Turkey.

\section{Conclusions}

Composition of the current account balance has featured that trade deficits were higher than the current account deficits which were more dangerous about sustainability and more open to debate about balance of payment crises since they indicate structural weaknesses in international trade and competitiveness. First, it can be argued confidently that there is interdependence between exports and imports since Turkey mostly exports final consumption goods whereas it imports intermediate goods. The dependence of export and production on the import was also detected by foreign trade structures and input-output tables. Income elasticity of import is 2.24 which imply that as the economy grows, current account deficits are unavoidable. For this reason, investments in the sectors should be evaluated according to their backward and forward linkages. In the production, if the shares of sectors 
Table 4. Composition of foreign debt stock.

\begin{tabular}{|c|c|c|c|c|c|}
\hline & Total Debt (Billion dollars) & Short Term Public (\%) & Short Term Private (\%) & Long Term Public (\%) & Long Term Private $(\%)$ \\
\hline 1989 & 43,879 & 0.02 & 0.11 & 0.83 & 0.04 \\
\hline 1990 & 52,377 & 0.02 & 0.17 & 0.78 & 0.04 \\
\hline 1991 & 53,623 & 0.02 & 0.15 & 0.78 & 0.05 \\
\hline 1992 & 58,595 & 0.02 & 0.20 & 0.72 & 0.06 \\
\hline 1993 & 70,512 & 0.01 & 0.25 & 0.66 & 0.08 \\
\hline 1994 & 68,705 & 0.01 & 0.15 & 0.74 & 0.10 \\
\hline 1995 & 75,948 & 0.02 & 0.19 & 0.70 & 0.10 \\
\hline 1996 & 79,299 & 0.01 & 0.20 & 0.65 & 0.13 \\
\hline 1997 & 84,356 & 0.01 & 0.20 & 0.59 & 0.20 \\
\hline 1998 & 96,351 & 0.03 & 0.19 & 0.54 & 0.25 \\
\hline 1999 & 103,123 & 0.02 & 0.20 & 0.51 & 0.27 \\
\hline 2000 & 118,602 & 0.03 & 0.21 & 0.51 & 0.25 \\
\hline 2001 & 113,592 & 0.02 & 0.13 & 0.61 & 0.24 \\
\hline 2002 & 129,546 & 0.02 & 0.11 & 0.65 & 0.23 \\
\hline 2004 & 160,977 & 0.03 & 0.17 & 0.57 & 0.23 \\
\hline 2005 & 169,872 & 0.03 & 0.20 & 0.48 & 0.30 \\
\hline 2006 & 207,761 & 0.02 & 0.18 & 0.40 & 0.40 \\
\hline 2007 & 249,425 & 0.02 & 0.16 & 0.34 & 0.49 \\
\hline 2008 & 280,444 & 0.02 & 0.17 & 0.31 & 0.50 \\
\hline 2009 & 268,764 & 0.02 & 0.16 & 0.34 & 0.48 \\
\hline 2010 & 290,350 & 0.02 & 0.25 & 0.33 & 0.40 \\
\hline
\end{tabular}

Source: CBRT, foreign debt statistics [16].

that have strong domestic linkages with the others increase, dependence of imported inputs can be decrea- sed. When the industries are ordered according to their volume of exports, it can be seen that top exporters are generally the top importers at the same time. Second, when the subject comes to the financing, it has been seen that current account deficits were over-financing by the financial account surpluses through FDI and long term credits in increasing amounts. Also, when compared to most of the developing countries in terms of the ratio of short term debt to the total and the ratio of public debt to the private debt, Turkey has seemed to be in a better position. However, two developments after world economic crisis have raised the doubts about the sustainability of the current account deficits in Turkey; short term debt of the private sector has sharply increased and share of FDI in financing account was much lower than the previous couple of years against the portfolio investments in 2010 .

Finally, current account deficit is a permanent problem in Turkey and cannot be solved easily since changing the production process and technological level of firms require long term planning and investments. In order to eliminate the current account deficits by decreasing import and trade deficits smoothly, Turkey may going to be faced with a slow growth period in near future, but the probability of a balance of payment crisis is still present as it was in the past.

\section{REFERENCES}

[1] G. Corsetti, P. Presenti and N. Roubini, "What Caused the Asian Currency for Financial Crisis?" NBER Working Papers No. 6833, Cambridge, 1998.

[2] G. M. Milesi-Ferretti and A. Razin, "Persistent Current Account Deficits: A Warning Signal?" International Journal of Finance and Economics, Vol. 1, No. 3, 1996, pp. 161-181.

doi:10.1002/(SICI)1099-1158(199607)1:3<161::AID-IJF E19>3.0.CO;2-W

[3] R. Glick and K. Rogoff, "Global versus Country-Specific Productivity Shocks and the Current Account," Journal of Monetary Economics, Vol. 35, No. 1, 1995, pp. 159-192. doi:10.1016/0304-3932(94)01181-9

[4] A. R. Ghosh and J. D. Ostry, "The Current Account in Developing Countries: A Perspective from the Consumption-Smoothing Approach," World Bank Economic Review, Vol. 9, No. 4, 1995, pp. 305-333. doi:10.1093/wber/9.2.305

[5] J. L. Wu, "Mean Reversion of the Current Account: Evidence from the Panel Data Unit Root Test," Economics Letters, Vol. 66, 2000, pp. 215-222.

[6] S. Husted, "The Emerging U.S. Current Account Deficit in the 1980s: A Cointegration Analysis," The Review of Economics and Statistics, Vol. 74, No. 1, 1992, pp. 159166.

[7] L. L. Leachman and B. B. Francis, "Multicointegration Analysis of the Sustainability of Foreign Debt," Journal of Macroeconomics, Vol. 22, No. 2, 2000, pp. 207-227.

[8] J. L. Wu, S. L. Chen and H. Y. Lee, "Are Current Account Deficits Sustainable? Evidence from Panel Cointegration," Economics Letters, Vol. 72, No. 2, 2001, pp. 219-224. doi:10.1016/S0165-1765(01)00420-7

[9] A. Z. Baharumshah, E. Lau and S. Fountas, "On the Sus- 
tainability of Current Account Deficits: Evidence from Four ASEAN Countries," Journal of Asian Economics, Vol. 14, No. 3, 2003, pp. 465-487. doi:10.1016/S1049-0078(03)00038-1

[10] S. Ongan, "The Sustainability of Current Account Deficits and Tourism Receipts in Turkey," International Trade Journal, Vol. 22, No. 1, 2008, pp. 39-62. doi: $10.1080 / 08853900701784060$

[11] H. Kalyoncu, "Sustainability of Current Account for Turkey: Intertemporal Solvency Approach,” MPRA No. 1220, Munich, 2007.

[12] Y. Matsubayashi, “Are US Current Account Deficits Unsustainable? Testing for the Private and Government Intertemporal Budget Constraints," Japan and the World Economy, Vol. 17, No. 2, 2005, pp. 223-237. doi:10.1016/S0922-1425(04)00008-8

[13] J. M. Campa and A. Gavilán, "Current Accounts in the Euro Area: An Intertemporal Approach," IESE Research Papers No. D/651, Barcelona, 2000.

[14] M. Raybaudi, M. Sola, F. Spagnolo, "Red Signals: Current Account Deficits and Sustainability," Economics Letters, Vol. 84, No. 2, 2004, pp. 217-223. doi:10.1016/j.econlet.2004.02.005

[15] E. Uygur, "Cari Açık Tartışmaları," İktisat, İşletme ve Finans, Vol. 19, No. 222, 2004, pp. 5-20.

[16] Central Bank of Republic Turkey, Database of Balance of Payments: Analytical Presentation, Ankara, 2011.

[17] B. A. Eşiyok, "Türkiye Ekonomisinde Üretimin ve İhracatın İthalata Bağımlılığı: Dış Ticaretin Yapısı," Uluslararası Ekonomi ve Dıș Ticaret Politikaları, Vol. 3, No.
1, 2008, pp. 117-160.

[18] Z. Yükseler and E. Türkan, “Türkiye'nin Üretim ve Diş Ticaret Yapısında Dönüşüm," TÜSİAD Report, No. 02453, Istanbul, 2008.

[19] M. Ersungur D. Ekinci and A. Takım, "Türkiye Ekonomisinde İthalata Bağımlılıktaki Değişme: Girdi-Çıktı Yaklaşımıyla Bir Uygulama," Atatürk Üniversitesi Iktisadi ve Ídari Bilimler Fakültesi Dergisi, Vol. 25, 2011, pp. 1-13.

[20] C. S. Hakkio, "The U.S. Current Account: The Other Deficit," Economic Review, Vol. 3, 1995, pp. 11-24.

[21] S. T. Ok, "Sustainability and Financing of Current Account Deficits: The Turkish Case," İktisat, İşletme ve Finans, Vol. 23, No. 272, 2008, pp. 7-24.

[22] R. C. Shelburne, "Current Account Deficits in the New Member States: Causes and Consequences," Intereconomics, Vol. 44, No. 2, 2009, pp. 90-95. doi:10.1007/s10272-009-0282-2

[23] L. R. Suarez and P. Ghezzi, "Current Accounts: Can They Achieve Sustainability?” Deutche Bank Global Market Research, 2004.

[24] H. D. Yan and C. L. Yang, "Foreign Capital Inflows and the Current Account Imbalance: Which Causality Direction?" Journal of Economic Integration, Vol. 23, No. 2, 2008, pp. 433-461.

[25] C. Freund and F. Warnock, "Current Account Deficits in Industrial Countries: The Bigger They Are, The Harder They Fall?" NBER Working Papers No. 11823, Cambridge, 2005. 